\title{
Spatial variation of physicochemical characteristics in Formosa papaya fruits
}

\author{
Variación espacial de las características fisicoquímicas en frutas \\ de la papaya Formosa \\ Nicolas Oliveira de Araújoํㄹ Edna Maria Mendes Aroucha ${ }^{*}$, Luan Vitor Nascimento ${ }^{1}$, \\ Rafaella Martins de Araújo Ferreira ${ }^{1}$, Welder de Araújo Rangel Lopes ${ }^{1}$
}

\begin{abstract}
In order to evaluate the postharvest quality of different parts of the papaya fruit, an experiment was conducted in the Postharvest Laboratory, Department of Agrotechnology and Social Sciences, Universidade Federal Rural do Semiárido, Mossoró, RN, in September 2009. The fruits were harvested at maturity stage 2, when the fruit has $25 \%$ of the rind yellow. The experimental design was completely randomized with 20 repetitions, each repetition a fruit. The fruits were cut into three parts: stalk, median and apical, in which we analyzed the following characteristics: outer and inner pulp firmness, titratable acidity (TA), pH, soluble solids (SS), vitamin $\mathrm{C}$ and the SS/TA ratio. The stalk region presented higher acidity and $\mathrm{pH}$ than the median and apical areas. The firmness of the outer pulp iswas greater than that observed inside the fruit. The highest levels of soluble solids and SS/TA were found in the apical and median parts, demonstrating that these regions have milder flavor than the stalk region.
\end{abstract}

Key words: Carica papaya, postharvest, soluble solids.

\section{RESUMEN}

La papaya es una fruta muy apreciada en las Américas. Su calidad está intrínsecamente asociada a sus características fisicoquímicas. En ese sentido se evaluó la calidad, después de la colecta de papaya Formosa. De esa manera un experimento fue realizado en el Laboratório de Tecnología de los Alimentos de la Universidad Rural del Semiárido (UFERSA), Mossoró, RN con 20 frutos recogidos sirve el período de maduración (hasta $25 \%$ de cáscara amarilla), siendo seleccionados en tres porciones distintas (peducular, mediana y apical) a partir de las que fueron analizadas las siguientes características: firmeza de la pulpa, acidez titulables, $\mathrm{pH}$, sólidos solubles, vitamina $C$ y índice de maduración. El delineamento experimental utilizado fue totalmente casualizado, com 20 repeticiones de un fruto. La firmeza externa de la pulpa fue superior a la firmeza interna de los frutos. La region peduncular presentó valores de acidez titulables y $\mathrm{pH}$ superior a las regiones pedical y medianas. Y los mayores índices de sólidos solubles e índice de maduración fueron detectados en las regiones apical y mediana, demonstando que esas regiones presentan sabores más prominentes que la región peduncular.

Palabras clave: Carica papaya, poscosecha, sólidos solubles.

\section{Introduction}

Papaya is a widely farmed fruit in tropical areas, and has found an auspicious environment with good climate for commercial cultivation in Brazil. Brazil is the second greatest world producer, with a production of 1,582,638 tons in 2013 (Faostat, 2015).

Consumption and marketing of papaya has increased throughout the world in the last decade (Morais et al., 2010). In Brazil papaya is the third most consumed fruit, with a per capita consumption of $2.0 \mathrm{~kg} /$ year ( $4.4 \mathrm{lbs} /$ year). The most cultivated varieties in Brazil are Solo (small fruit) and Formosa (large fruit). The Solo variety is preferable for exportation, due to its reddish pulp and reduced size; the fruit weighs between 300 and $650 \mathrm{~g}$ (Dias et al., 2011). Formosa fruit (>1.000 g) is mainly destined for internal consumption; however, in recent years the external market, especially Canada, has increased demand for fruit of this variety.

Postharvest quality is important; due to a growing demand of the external market it is indispensable that the fruit reach the market in perfect conditions for consumption. Papaya is a climacteric fruit with

\footnotetext{
1 Universidade Federal Rural do Semi-Árido, Mossoró, Rio Grande do Norte, Brasil.

* Corresponding author: aroucha@ufersa.edu.br
} 
no starch stock, therefore following the regulations of the Brazilian Ministry of Agriculture it must be harvested with a level of soluble solids of at least $11^{\circ} \mathrm{Brix}$ (Brasil, 2009) to assure good quality after maturation.

The soluble solids content is the quality index most used to determine the sweetness of papaya fruit. This index normally indicates a proportion of $73 \%$ soluble sugars present in fruits (Rocha et al., 2007). Fruits with higher content of soluble solids are preferred for fresh consumption and processing. Papaya pulp has on average an acidity of $0.13 \%$ citric acid, pH 4.55 and $97.6 \mathrm{mg} 100 \mathrm{mg}^{-1}$ vitamin C (Freitas et al., 2015). However, it is important to remember that the physicochemical characteristics of papaya may vary depending on the cultivar, maturation stage and the region. There is no study in the literature of the characteristics of the different parts of Formosa papaya fruit. With the exception of industrial pulp processing, the study of quality characteristics in different parts of papaya fruit may result in important practical information, mainly for fruits destined for fresh consumption and minimal processing, because some consumers have daily restrictions of sugar consumption, which is papaya's main component.

In watermelon, the distribution of bioactive compounds varies in different parts of the fruit pulp; the main concentration is in the central region of the fruit (Tliti et al., 2011). Variation in soluble sugar concentration, bioactive compounds, minerals and enzymatic activity have also been found, depending on the area studied in melon (Lester, 2008).

Based on these considerations, this study's goal was to evaluate the spatial variation of the physicochemical characteristics of Formosa papaya fruits.

\section{Materials and Methods}

The experiment was performed in the Laboratório de Tecnologia de Alimentos of the Departamento de Agrotecnologia e Ciências Sociais at the Universidade Federal Rural do Semi-Árido, Mossoró-RN, in September 2009, with papaya fruits from a commercial field at the city of Baraúna-RN, located at latitude $5^{\circ} 05^{\prime} \mathrm{S}$ and longitude $37^{\circ} 38^{\prime} \mathrm{W}$, at an altitude of 95 meters. The region's climate, according to the Köppen Climate Classification System, is BSwh, with two climatic seasons: the dry season, usually between June and January, and the rainy season from February to May (Carmo Filho et al., 1991).

Formosa papaya fruits were harvested at physiological maturity (with $25 \%$ yellow rind). The experimental design was completely randomized with 20 repetitions; each repetition was a single fruit. Fruits were sliced into three parts-stalk, median and apical; we analyzed the following physicochemical parameters: Firmness: measured in the external and internal parts of the pulp, using a McCormick FT 327 analogic penetrometer with an $8.0 \mathrm{~mm}$ diameter tip. The measurements given in the unit of pound-force (lbf) were converted to Newtons (N) by multiplying by the factor 4.4482 ; Soluble solids content (SS): determined in the juice using a Palette PR-100 digital refractometer (Attago Co. Ltd., Japan), with an automatic temperature correction range between 0 and $32^{\circ}$ Brix (AOAC 1992); pH: determined directly from the juice using a digital Marte MB-10 pH meter (AOAC 1992); Titratable acidity (TA): measured following the recommendation of the Insituto Adolfo Lutz (1985), determined by titration of a $10 \mathrm{~mL}$ aliquot of the juice, in duplicate, to which $40 \mathrm{~mL}$ distilled water was added. Titration was accomplished using $0.1 \mathrm{~N}$ sodium hydroxide $(\mathrm{NaOH})$. The results were expressed as a percentage; Ripening index (SS/ TA): obtained by dividing the soluble solids level by the acidity; Vitamin C: determined by titration using the Tillman method (Strohecker and Henning 1967). The vitamin $C$ determination was performed immediately after pulp processing, by titration with 0.02\% 2,6-dichlorophenol indophenol (DCPIP) until the pink color in the liquid stays permanent, using $10 \mathrm{~g}$ of the sample diluted in $50 \mathrm{~mL} 0.5 \%$ oxalic acid. The results were expressed in $\mathrm{mg}$ of ascorbic acid/100 g pulp.

The results were submitted to analysis of variance (ANOVA) and the means were compared with the Tukey test $(\mathrm{p}<0.05)$ using the SISVAR statistical software (Ferreira, 2000).

\section{Results and Discussion}

Significant variation was found between fruit parts for all evaluated parameters except vitamin $\mathrm{C}$ (Figures 1, 2, 3, 4, 5 and 6). External pulp firmness was greater than that observed in the internal part, with averages of 55.03 and $16.30 \mathrm{~N}$, respectively (Figure 1). Since papaya ripens from the inside out (Lazan et al., 1989), the data collected in this 


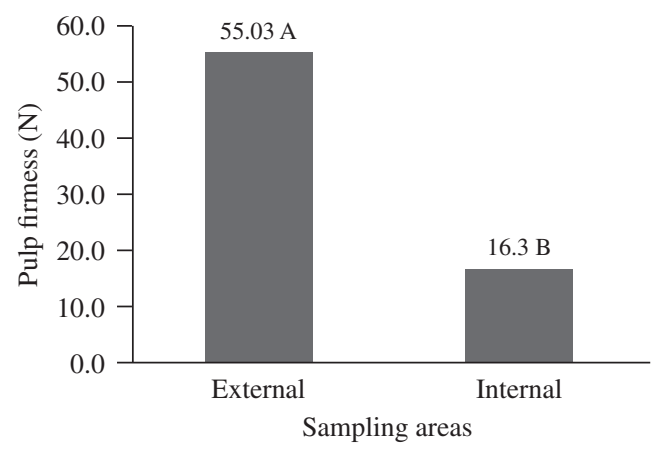

Figure 1. External and internal firmness of Formosa papaya.

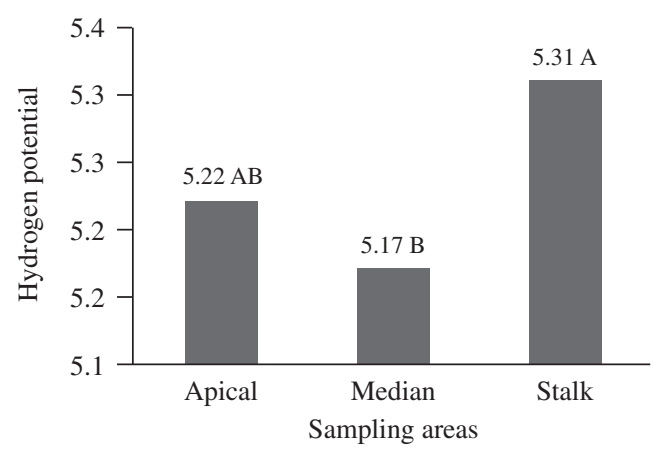

Figure 2. Titratable acidity of Formosa papaya fruit in different sampling areas.

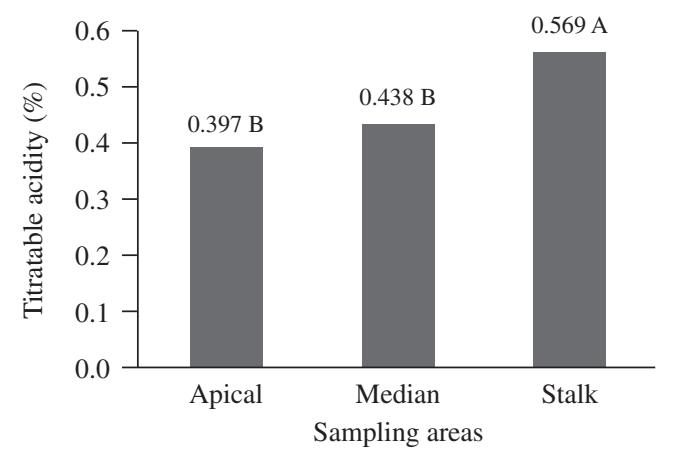

Figure 3. Hydrogen potential of Formosa papaya fruit in different sampling areas.

study were consistent. As the fruit matures the pectins from the cell wall become increasingly hydrated and partially hydrolyzed, reducing gel cohesion, facilitating molecular unbundling and completely changing the final texture of the ripened fruit (Crookes and Grierson, 1983). According to Bron and Jacomino (2011), papaya fruits with pulp

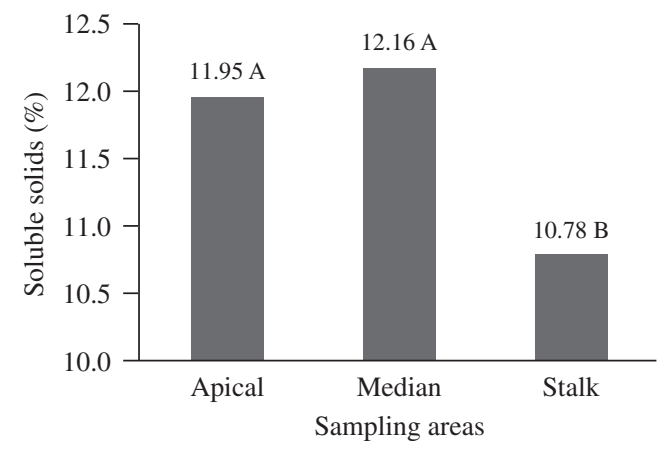

Figure 4. Soluble solids of Formosa papaya fruit in different sampling areas.

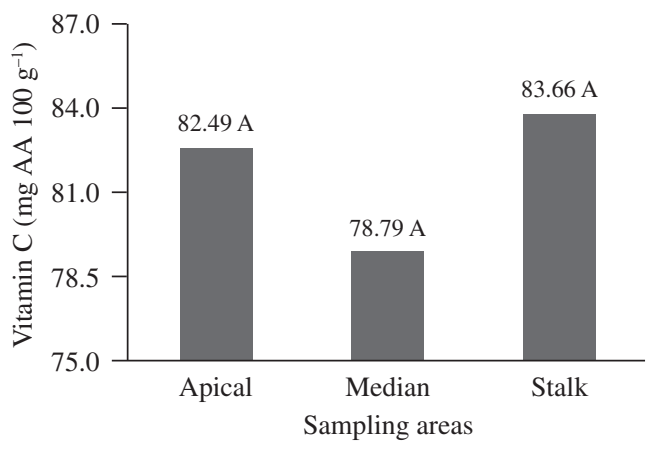

Figure 5. Vitamin C of Formosa papaya fruit in different sampling areas.

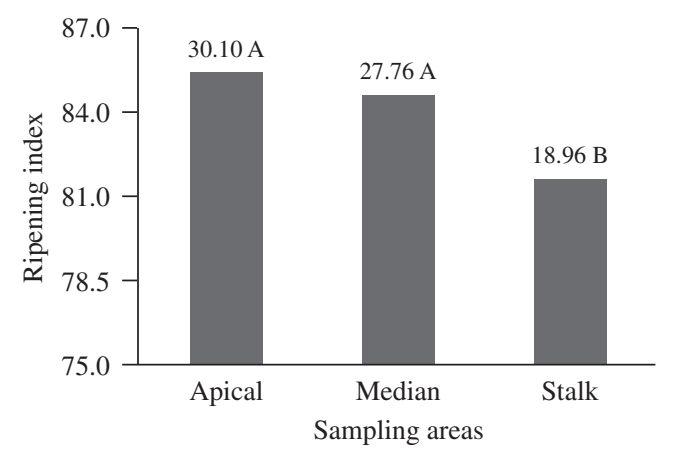

Figure 6. Ripening index of Formosa papaya fruit in different sampling areas.

firmness $\leq 20 \mathrm{~N}$ have better organoleptic quality for consuming.

Figure 2 shows that the apical and median parts presented similar titratable acidity, with averages of $0.397 \%$ and $0.438 \%$, respectively, less than the stalk $(0.569 \%)$. Chitarra and Chitarra (2005) indicated that fruits usually reduce acidity during maturation 
in proportion to the increasing metabolism after harvest, resulting in higher intake of organic acids as substrate for the respiratory process and greater simple sugar conversion. Papaya fruit acidity is low compared to other fruit species, usually showing values lower than $0.2 \%$ citric acid. The main acids are citric and malic, followed by alpha-ketoglutaric acid, which along with ascorbic acid contribute $85 \%$ of all papaya acids (Chan et al., 1971).

Higher $\mathrm{pH}$ values were found in the stalk region of the fruit, not too different from the apical region, which did not differ from the median part, with averages of 5.31,5.22, and 5.17, respectively (Figure 3). Organic acids present in plant tissue are always associated with their sodium $(\mathrm{Na})$ and potassium (K) salts, composing buffer systems which hamper $\mathrm{pH}$ fluctuation. The buffer capacity of some juices allows that even with large titratable acidity variations the $\mathrm{pH}$ does not vary significantly (Chitarra and Chitarra, 2005).

The soluble solids level of the median and apical regions were similar $(12.16 \%$ and $11.95 \%$, respectively), but were higher in the stalk region (10.78\%). Silva et al. (2002), studying different fruits of temperate climates, reported higher concentration of soluble solids in the apical region in prune, apple, nectarine and peach and in the median part of pear. However, Chitarra and Chitarra (2005) emphasized that SS spatial distribution in the fruit varies and can be measured by infrared spectrometry image or hyperspectral image, or even with the methodology applied in this study.

Sandri et al. (2011) verified spatial variation in chemical composition in pineapple fruit pulp, where the basal region showed higher levels of sugars and the apical region was more acid and humid. Sugar concentration in melon varied with the mesocarp region sampled; sucrose and total sugars predominate in the portion closer to the cavity, the opposite of glucose and fructose, which prevailed in tissues closer to the epicarp (Lester, 2008).
The spatial variation in papaya physicochemical composition may be explained in part by the phytohormones in its pulp, as in mango (Nodey et al., 2014). As in papaya the ripening process occurs from the inside out (Lazan et al., 1989), it probably begins ethylene autocatalytic synthesis in regions closer to the seed, producing less acidity (Figure 2) and more soluble solids (Figure 4) in the central and apical parts of the fruit.

No significant differences between the levels of vitamin $\mathrm{C}$ were detected in the different parts of the fruit (Figure 5). The average values reported here are higher than those reported by Rocha et al. (2007), who found an average of $49.42 \mathrm{mg} \mathrm{AA} / 100 \mathrm{~g}$ of papaya pulp for the harvest period, while Souza et al. (2005), analyzing the processed Formosa variety of papaya found an average of $76.7 \mathrm{mg} \mathrm{AA} / 100 \mathrm{~g}$ pulp.

The SS/TA ratio or ripening index presented higher values in the apical and median regions than in the stalk region. This suggests that the high sugar level, related to the low level of acidity, makes the apical and median parts taste smoother and more palatable than the stalk region of the fruit. Although the ripening index is one of the most used ways to evaluate fruit taste it may not be the most adequate way, considering that it depends on soluble solids content and titratable acidity. A proportion could be established as in melon, where the best taste was detected at a proportion equal or superior to 25:1, with the acidity less than $0.5 \%$ (Cruess, 1973).

\section{Conclusion}

The external firmness of the fruit pulp is greater than that observed within the fruit.

The stalk region presents higher tritratable acidity and $\mathrm{pH}$ than the apical and median regions.

Higher levels of soluble solids and the ripening index are found at the apical and median regions, demonstrating that these regions present smoother flavor than the stalk region.

\section{Literature Cited}

AOAC - Association Of Oficial Analytical Chemistral.

1992. Official methods of Analysis of the Association of Official Analytical Chemistry. 11. ed. AOAC. Washington D.C., USA 1115 p.

Brasil, Ministério da Agricultura e Abastecimento.

2007. Portaria No 348, de 27 de Dezembro de 2006. Estabelece os Procedimentos para a Caracterização, Implantação e Manutenção do Sistema Integrado de
Medidas Fitossanitárias para o Manejo de Risco das Pragas - Ceratitis capatata e Anastrepha fraterculos em 86 Frutos frescos de Mamão (Carica papaya L). Diário Oficial da União, Brasília.

Bron, I.U.; Jacomino, A.P. 2006. Ripening and quality of 'Golden' papaya fruit harvested at different maturity stages. Brazilian Journal of Plant Physiology, 18 (3): 389-396. 
Carmo Filho, F.; Espínola Sobrinho, J.; Maia Neto, J.M. 1991. Dados climatológicos de Mossoró: um município semi-árido nordestino. ESAM. Mossoró, Brasil, 121 p.

Chitarra, M.I.F.; Chitarra, A.B. 2005. Pós-colheita de frutos e hortaliças: fisiologia e manuseio. 2 ed. UFLA. Lavras, Brazil, 785 p.

Crookes, P.R.; Grierson, D.

1983. Ultrastructure of tomato fruit ripening and the role of polygalacturonase isozymes in cell wall degradation. Plant Physiology, 72 (4): 1088-1095.

Cruess, W.V.

1973. Produtos industrializados de frutas e hortaliças. Tradutor, Heitor Airlie Tavares. Edgrad Blucher. Vol. II. São Paulo, Brasil, 854 p.

Dias, N.L.P.; Oliveira, E.J.; Dantas, J.L.

2011. Avaliação de genótipos de mamoeiro com uso de descritores agronômicos e estimação de parâmetros genéticos. Pesquisa Agropecuária Brasileira, 46 (11): 1471-1479.

Faostat

2015. Food and Agriculture Organization of the United Nations. Production, crops. Disponível em: <http://faostat.fao.org/ DesktopDefault.aspx?PageID=339\&lang=es $>$. Acesso em: 31 out.

Ferreira, D.F.

2000. Análises estatísticas por meio do Sisvar para Windows versão 4.0. In: Reunião Anual da Região Brasileira da Sociedade Internacional de Biometria, 45. Anais... São Carlos: SIB, pp. 255-258.

Chan, H.T. Jr.; Chang, T.S.K.; Stafford, A.E.; Brekke, J.E.

1971. Nonvolatile acids of papaya. Journal of Agricultural and Food Chemistry, 19 (2): 263-265.

Lazan, H.; Ali, Z.M.; Liang, K.; S.; Yee, K.L.

1989. Polygalacturonase activity and variation in ripening of papaya fruit with tissue depth and heat treatment. Physiologia Plantarum, 77 (1): 93-98.
Lester, G.E.

2008. Antioxidant, sugar, mineral, and phytonutrient concentrations across edible fruit tissues of orange-fleshed honeydew melon (Cucumis melo L.). Journal of Agricultural and Food Chemistry, 56 (10): 3694-3698.

Morais, F.A.; Araújo, F.M.M.C.; Machado, AV.; Ricarte, F.D.N.; Junior, R.S.

2010. Influência da atmosfera modificada sob a vida útil póscolheita do mamão 'Formosa'. Revista Verde de Agroecologia e Desenvolvimento Sustentável, 5 (4): 01-09.

Noday, T.; Léchaudel, M.; Genard, M.; Joas, J.

2014. Spatial and temporal variations in mango colour, acidity, and sweetness in relation to temperature and ethylene gradients within the fruit. Journal of Plant Physiology, 171 (17): 1555-1563.

Rocha, R.H.C.; Menezes, J.B.; Nascimento, S.R.C.; Nunes, G.H.S. 2007. Qualidade do mamão 'Formosa' submetido a diferentes temperaturas de refrigeração. Revista Caatinga, 20 (1): 75-80.

Sandri, D.O.; Porto, A.G.; Silva, F.S.; Pastro, D.C.; Paglarini, C.S. 2011. Análise físico-química do abacaxi cultivar Pérola na forma in natura em diferentes posições do fruto: cilindro central e polpa. Enciclopédia Biosfera, 7 (13): 1378-1384.

Silva, P.S.L.; Sá, W.R.; Mariguele, K.H.; Barbosa, A.P.R.;

Oliveira, O.F.

2002. Distribuição do teor de sólidos solúveis totais em frutos de algumas espécies de clima temperado. Revista Caatinga, 15 (1/2): 19-23.

Souza, B.S.; Durigan, J.F.; Donadon, J.R.; Teixeira, G.H.A. 2005. Conservação de mamão 'Formosa' minimamente processado armazenado sob refrigeração. Revista Brasileira de Fruticultura, 27 (2): 273-276.

Strohecker, R.; Henning, H.M.

1967. Analisis de vitaminas: métodos comprobados. Paz Montalvo. Madrid, España, 428 p. 
